\title{
Hesa-A Effects on Cell Cycle Signaling in Esophageal Carcinoma Cell Line
}

\author{
Nasser Ahmadian ${ }^{1}$, Roghiyeh Pashaei-Asl ${ }^{2}$, Nasser Samadi ${ }^{2}$, Mohammad Rahmati-yamchi ${ }^{3}$, \\ Mohammad-Reza Rashidi ${ }^{4}$, Masomeh Ahmadian ${ }^{1}$, Moosa Esmaeili ${ }^{5}$, \\ Faezeh Salamat ${ }^{6}$, Sima Besharat ${ }^{6}$, Hamid Reza Joshaghani ${ }^{* 6}$
}

\section{Faculty of Advanced Medical Science Technology, Golestan University of Medical Sciences, Gorgan, Iran \\ 2. Faculty of Advanced Biomedical Sci- ences, Tabriz University of Medical Sci- ences, Tabriz, Iran \\ 3. Department of Biochemistry, Tabriz Uni- versity of Medical Sciences, Tabriz, Iran \\ 4. Research Center for Pharmaceutical Nanotechnology, Faculty of Pharmacy, Tabriz University of Medical Sciences, Tabriz, Iran \\ 5. Women's Reproductive Health Research Center, Alzahra Hospital, Tabriz Univer- sity of Medical Sciences, Tabriz, Iran \\ 6. Golestan Research Center of Gastroen- terology and Hepatology, Golestan Uni- versity of Medical Sciences, Gorgan, Iran}

\section{* Corresponding Author:}

Golestan Research Center of Gastroenterology and Hepatology, 3rd floor, Research Centers' Complex, Sayyad-e-Shirazi Hospital, Sayyad-e-Shirazi Boulevard, Gorgan, Golestan province, Iran Postal code: 41448-95655

Tel: + 981732369210

Fax: + 981732369210

Email: joshaghani@goums.ac.ir

Received: 05 May 2016

Accepted: 10 Sep. 2016

\section{ABSTRACT}

\section{BACKGROUND}

Hesa-A is a natural compound with anticancer properties. The exact mechanism of its action in esophageal cancer is not clear, yet. The aim of this study was to evaluate the cell toxicity effect of Hesa-A on the esophageal carcinoma cell lines, KYSE-30, and cell cycle genes expression.

\section{METHODS}

In this study, we tested cell toxicity with MTT (3-(4,5-Dimethylthiazol2-yl)-2,5-Diphenyltetrazolium Bromide) assay and flow cytometry to evaluate the cell cycle arrest. Real time polymerase chain reaction was used to assess the expression of P53, P16, P21, cyclin D1, and cyclin B1 genes.

\section{RESULTS}

Our results showed that Hesa-A is effective in the expression of cell cycling check point proteins. Hesa-A induced an arrest in G2 phase of esophageal cell cycle. The levels of P53 (>13 times), P21 (>21 times), P16, cyclin B1, and cyclin D1 genes were increased 48 hours after Hesa-A treatment.

\section{CONCLUSION}

P21 and P16 expression were the potential mechanisms for G2 arrest of KYSE-30 esophageal cancer cell line by Hesa-A.

\section{KEYWORDS}

Hesa-A; Esophageal cancer; Flow cytometry; Real Time PCR; P53 gene; P16 gene; P21 gene; Cyclin D1 gene; Cyclin B1 gene.

Please cite this paper as:

Ahmadian N, Pashaei-Asl R, Samadi N, Rahmati-yamchi M, Rashidi MR, Ahmadian M, Esmaeili M, Salamat F, Besharat S, Joshaghani HR. Hesa-A Effects on Cell Cycle Signaling in Esophageal Carcinoma Cell Line. Middle East J Dig Dis 2016;8:297-302. DOI :10.15171/mejdd.2016.39

\section{INTRODUCTION}

Esophageal squamous cell carcinoma occurs in 50 of 100,000 individuals each year in the northeast Iran (Golestan region), which is one of the highest rates in the world. ${ }^{1}$ Various genes are contributed in the suppression of cancer cells, but sometimes their expression is changed, which leads to the cancer development. $^{2}$

P53 (from P53 gene) is an anti-oncogene nuclear protein, which has critical role in the apoptosis and cell cycle. ${ }^{3-5}$ Its function accomplishes through activation of downstream genes like $\mathrm{P} 21 .{ }^{6} \mathrm{P} 21$ and $\mathrm{P} 16$ proteins are cyclin dependant kinas inhibitors involving in cell cycle arrest. Cyclin D1 and cyclin B1 
are members of cyclin protein family, which regulate cell cycle progression. ${ }^{7}$ G2-M transition is being controlled by cyclin B1. In addition, P53 prevent the G2 to M phase transition through declining the level of cyclin $\mathrm{B} .{ }^{8}$

Chemotherapeutic drugs are mostly used in the treatment of the metastatic forms of cancers, in which many of them (more than $80 \%$ ) are derived from plant compounds. ${ }^{9}$ Recently the use of natural medicines for cancer therapy has been considered. Hesa-A is a natural biological drug with marine-herbal origin, which is patented in IRAN. ${ }^{10}$ Islamic Republic of Iran's Ministry of Health and Medical Education permitted the mass production of Hesa-A (registration number: D-5-6638; dated on 14/06/2005). ${ }^{11}$ As it is said by the inventor of this drug, Hesa-A contains Penaeus latisculatus (king prawn), Carum carvi, and Apium graveolens. A mixture of calcium carbonate, magnesium (sulfate and phosphate), potassium (sulfate and phosphate), are sodium (sulfate and phosphate), are the mineral content of this drug. Other elements in salt or complex forms in the Hesa-A compound including: arsenic (As), bromine $(\mathrm{Br})$, barium $(\mathrm{Ba})$, cesium $(\mathrm{Cs})$, copper $(\mathrm{Cu})$, erbium $(\mathrm{Er})$, lutetium (Lu), manganese (Mn), nickel (Ni), strontium (Sr), silver (Ag), thallium (Ti), tellurium (Te), thulium (Tm), titanium (Ti), tungsten $(\mathrm{W})$, vanadium $(\mathrm{Va})$, and zinc $(\mathrm{Zn}) .^{12}$

This drug has antioxidant and anticancer properties. Also it has the ability to inhibit cell growth in cancer cells. ${ }^{13,14}$ Yet, its mechanism in esophageal cancer is not defined very well.

In this study, we used KYSE-30 cell line as human epithelial esophageal cancer cell line derived from esophageal squamous cell carcinoma. 3-(4,5-dimethlthiazol-2-yl)-2,5-diphenyltetrazolium Bromide (MTT) assay was used to investigate the cytotoxicity of HesaA on esophageal malignancy cell line (KYSE-30). Flow cytometry was used to assess the effect of Hesa-A on KYSE-30 cell cycle arrest and real-time polymerase chain reaction (PCR) was used to evaluate the P53, P21, $\mathrm{P} 16$, cyclin D1, and cyclin B1 genes expression after Hesa-A treatment.

\section{MATERIALS AND METHODS}

\section{Cell culture}

The human esophageal carcinoma cell line, KYSE30 , was cultivated as previously described. ${ }^{15}$ Then, 96- well flat-bottomed culture plates (TPP, Switzerland) were used to seed the cells into them for further MTT assay or 6-well plate (TPP, Switzerland) was applied for real time PCR and flow cytometry. Then they were incubated at $37^{\circ} \mathrm{C}$ in a $5 \% \mathrm{CO}_{2}$ incubator.

\section{MTT assay}

For MTT assay we used 5000 viable cells per well in 96-well bottom flatted plate (SPL, Korea) and incubated at $37{ }^{\circ} \mathrm{C}$ and $5 \% \mathrm{CO}_{2}$ in a humidified environment. The cells were treated with Hesa-A in different concentrations after 24 hours, and were incubated more for additional 24 hours for MTT assay. MTT solution ( $0.5 \mathrm{mg}$ / $\mathrm{mL}$ ) was added to each well after the time passed and they were incubated at $37^{\circ} \mathrm{C}$ for 4 hours. Then, after removing the medium the blue formazan crystals were dissolved in $200 \mu \mathrm{L}$ of DMSO(Dimethyl sulfoxide) and $25 \mu \mathrm{L}$ Sorenson buffer. A microplate reader (Biotek, model Elx808) was used to read the absorbance at 570 $\mathrm{nm}$. Each experiment was repeated for three times.

\section{Flow cytometry}

To assess the cell cycle arrest 300,000 viable KYSE30 cells were cultured in 6-well tissue culture plate (SPL, Korea). After 24 hours they were treated with $0.8 \mathrm{mg} / \mathrm{mL}$ Hesa-A for 24 and 48 hours. Then, the cells were suspended in cold $70 \%$ ethanol and incubated on ice for 30 minutes. After an appropriate time, the cells were washed in PBS and RNAse A (INtRON) was added at $37^{\circ} \mathrm{C}$ for 30 minutes. Then, it was stained with PI (propidium iodide) in the dark. Cell population undergoing cell cycle phases was obtained by BD FACS Calibur flow cytometry and the data were analyzed using FlowJo software.

\section{RNA extraction and c-DNA synthesis}

Similar to flow cytometry, we used 300,000 viable cells per each 6-well tissue culture plate and incubated overnight. Then Hesa-A was treated for 24 and 48 hours and left in incubator. After that, the medium was removed and Cinagene Kit (RNX-Plus Solution, SinaClon, Iran) was used to extract the total RNA from each sample. CDNA synthesis kit (Qiagene) was used for cDNA synthesis.

\section{Real-time PCR}


Table 1: Primer sequences used in real-time PCR

\begin{tabular}{ccc}
\hline Genes & \multicolumn{2}{c}{ Primer sequences } \\
\hline \multirow{2}{*}{ P53 } & Forward & GTT CCG AGA GCT GAA TGA GG \\
\cline { 2 - 3 } & Reverse & ACT TCA GGT GGC TGG AGT GA \\
\hline \multirow{2}{*}{ P16 } & Forward & CCT CGT GCT GAT GCT ACT GA \\
\cline { 2 - 3 } & Reverse & CAT CAT CAT GAC CTG GTC TTC T \\
\hline \multirow{2}{*}{ P21 } & Forward & GCT TCA TGC CAG CTA CTT CC \\
\cline { 2 - 3 } & Reverse & CCC TTC AAA GTG CCA TCT GT \\
\hline \multirow{2}{*}{ Cyclin B1 } & Forward & GCC TCT ACC TTT GCA CTT CC \\
\cline { 2 - 3 } & Reverse & TGC TGC AAT TTG AGA AGG AG \\
\hline \multirow{2}{*}{ Cyclin D1 } & Forward & GCG GAG GAG AAC AAA CAG AT \\
\cline { 2 - 3 } & Reverse & TGA ACT TCA CAT CTG TGG CA \\
\hline
\end{tabular}

Real-time PCR with Rotor-Gene 6000 real-time PCR Detection System (Corbett, UK) was applied to determine the effect of Hesa-A on the P53, P16, P21, cyclin $\mathrm{D} 1$, and cyclin B1 genes expression in esophageal carcinoma. First-strand cDNA was amplified for various mRNA, using P53, P16, P21, cyclin D1, and cyclin B1. Table 1 shows the primers used in this study. $\beta$-Actin was used for housekeeping genes.

\section{Statistical analysis}

Microsoft Office Excel 2007 software was used for statistical analysis. Results were expressed as mean, standard deviation, and correlation coefficients (R2) and were compared with the cells without treatment (control group). $\mathrm{P}$ values $\leq 0.05$ were considered as statistically significant.

\section{RESULTS}

\section{MTT assay}

24 hours after treatment of the cells, MTT assay was performed to measure the cytotoxic effect of Hesa-A on the KYSE-30 cell lines proliferation. The human esophageal cancer cell line (KYSE-30) was treated with a variety of Hesa-A concentration (from $0.025 \mathrm{mg} / \mathrm{mL}$ to $0.8 \mathrm{mg} / \mathrm{mL}$ ) and was compared with the control group (untreated KYSE-30 cell lines, figure 1).

\section{Flow cytometry}

The percentage of treated cells and controls in each phase of the cell cycle was compared using flow cytometry. As shown in figures $2 \mathrm{~A}$ and $\mathrm{B}$, Hesa-A increased the cell percentage in $\mathrm{G} 2$ phase after 24 and 48 hours (figures $2 \mathrm{~A}$ and $2 \mathrm{~B}$ ).

\section{Analysis of the paclitaxel effect on expression of P53, P16, P21}

To determine the gene expression, real-time PCR analysis was done. The relative expression for each group was measured after normalization of the $\mathrm{Ct}$ values of P53, P21, P16, cyclin B1, and cyclin D1 genes in KYSE-30 treated cells according to the mRNA level of $\beta$-actin (as housekeeping gene). After 24 and 48 hours of Hesa-A treatment, the levels of P53, P21, P16, cyclin B1, and cyclin D1 genes increased. Level of P53 increased more than 13 times than the control group, and also its downstream gene (P21) increased significantly (more than 20 times compared with the control group, figure $3 \mathrm{~A}$ and $\mathrm{B})$.

\section{DISCUSSION}

Our study focused on the effect of Hesa-A on the esophageal carcinoma cell lines. Also cell cycle genes were investigated in this study. An arrest in G2 phase of esophageal cell cycle, was induced by Hesa-A. Also, after 24 hours P21 gene expression was raised. This raise was significant after 48 hours of treatment. P53 gene expression increased after 24 hours, too. But cyclin D1, and cyclin B1 genes expression decreased after time of treatment passed. So, in this study the potential mechanisms for G2 arrest of KYSE-30 esophageal cancer cell line by Hesa-A was through the P21 and P16 expression. After 48 hours, 2.23 times more expression of cyclin D1 gene was detected, but after 24 and 48 hours the gene expression level of cyclin B1 was less than untreated group.

The cell cycle-associated proteins are represented by P53, P21, and P16. They also play essential roles in cell proliferation and tumor cells. ${ }^{16}$ As a suppressing tumor protein, P53 regulates and modulates some cell pathway, DNA repair, apoptosis, and cell cycle. ${ }^{17} \mathrm{P} 53$ affects P21 expression, and consequently $\mathrm{P} 21$ induction could cause cell cycle arrest and prevent tumor progression. ${ }^{18} \mathrm{P} 16$ could prevent cell cycle development and encourages apoptosis or growth arrest. ${ }^{19}$ Furthermore, it has been shown that cyclin D1 down-regulation represents DNA repair, but cyclin D1 over- expression prevents DNA repair. ${ }^{20}$

It seems that increasing P35 expression after HesaA treatment, decreases the level of cyclin B. Previous studies showed that P53 prevents G2 to M phase transi- 


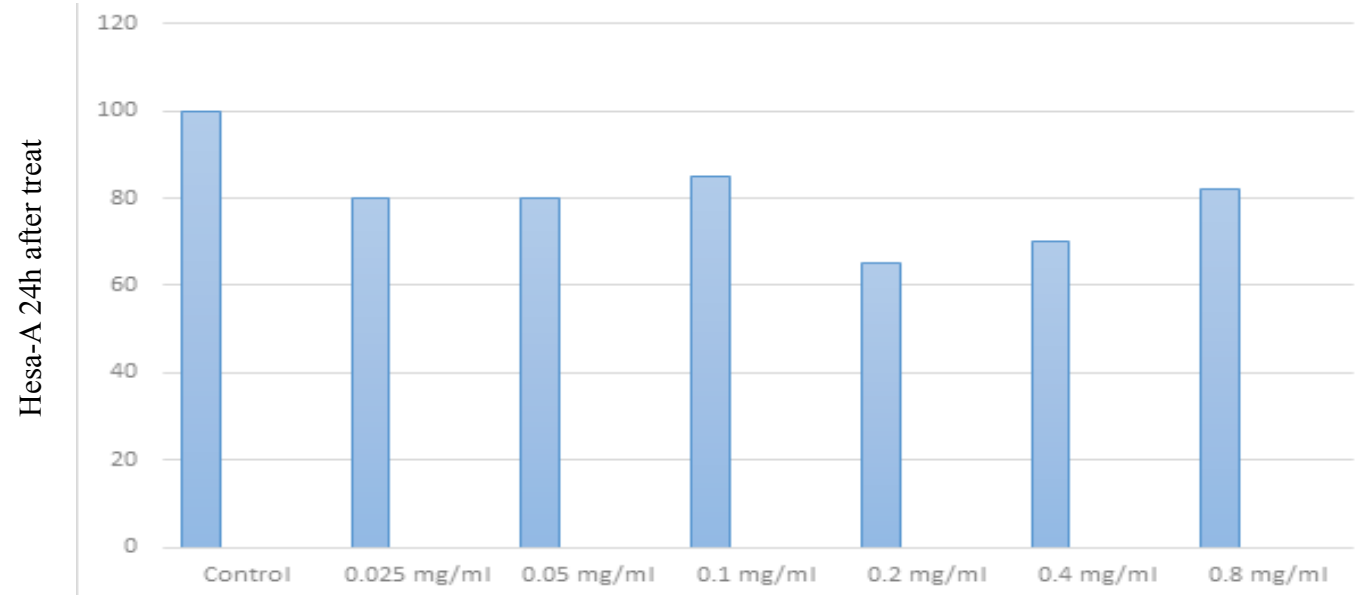

Hesa-A concentration

Fig.1: MTT assay measured the effect of Hesa-A on esophageal carcinoma cell line growth 24 hours after treatment. All data were normalized with control group (not treated with Hesa-A). The experiments were repeated three times.
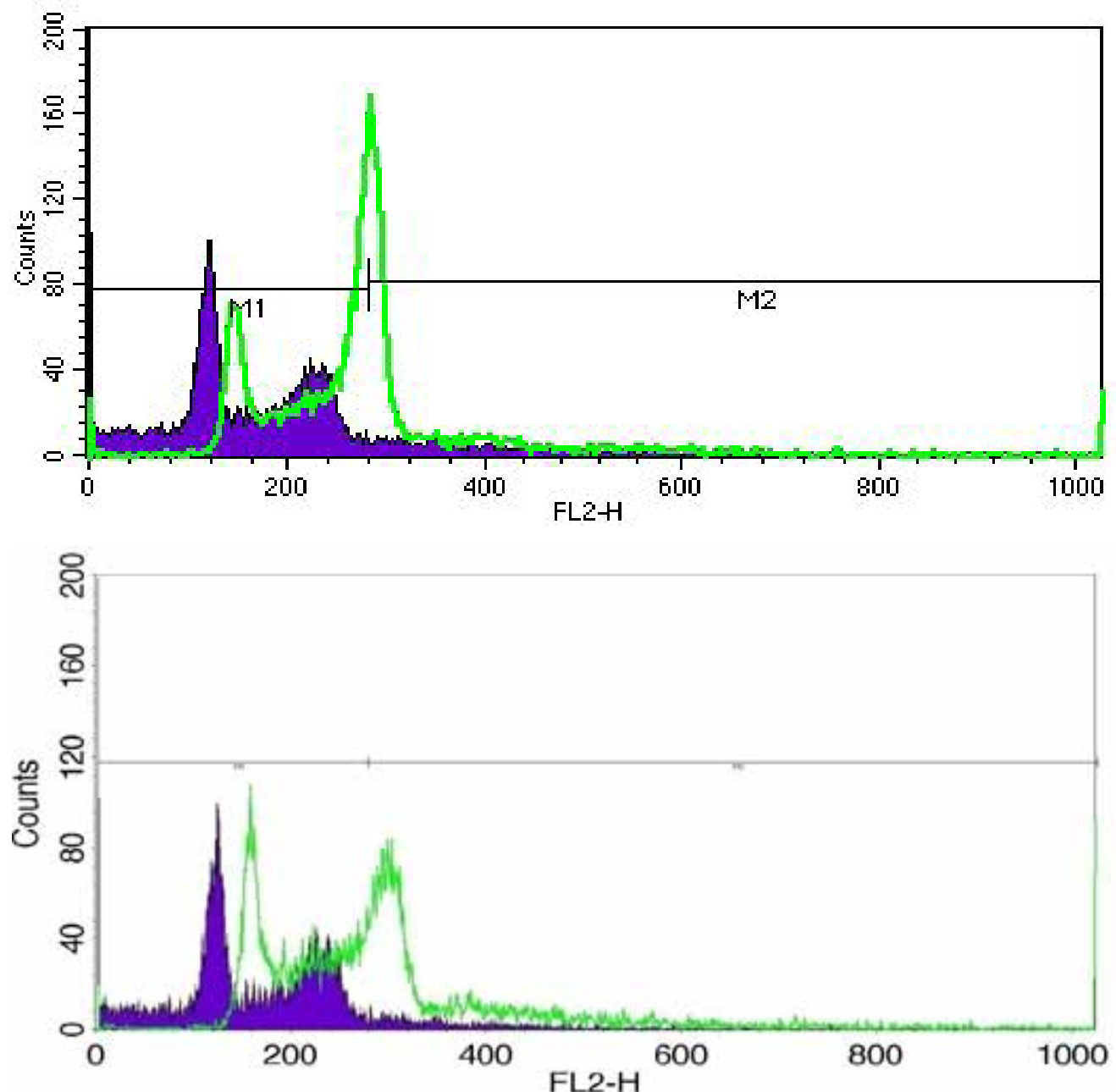

Fig.2: Hesa-A induces cell cycle arrest. Cell cycle arrest after (A) 24h and (B) 48 hours treatment with Hesa-A $(0.8 \mathrm{mg} / \mathrm{mL})$ compared with the controls. Purple color shows the control cells without Hesa-A and green color represents the cell cycle arrest of Hesa-A treated cells. 

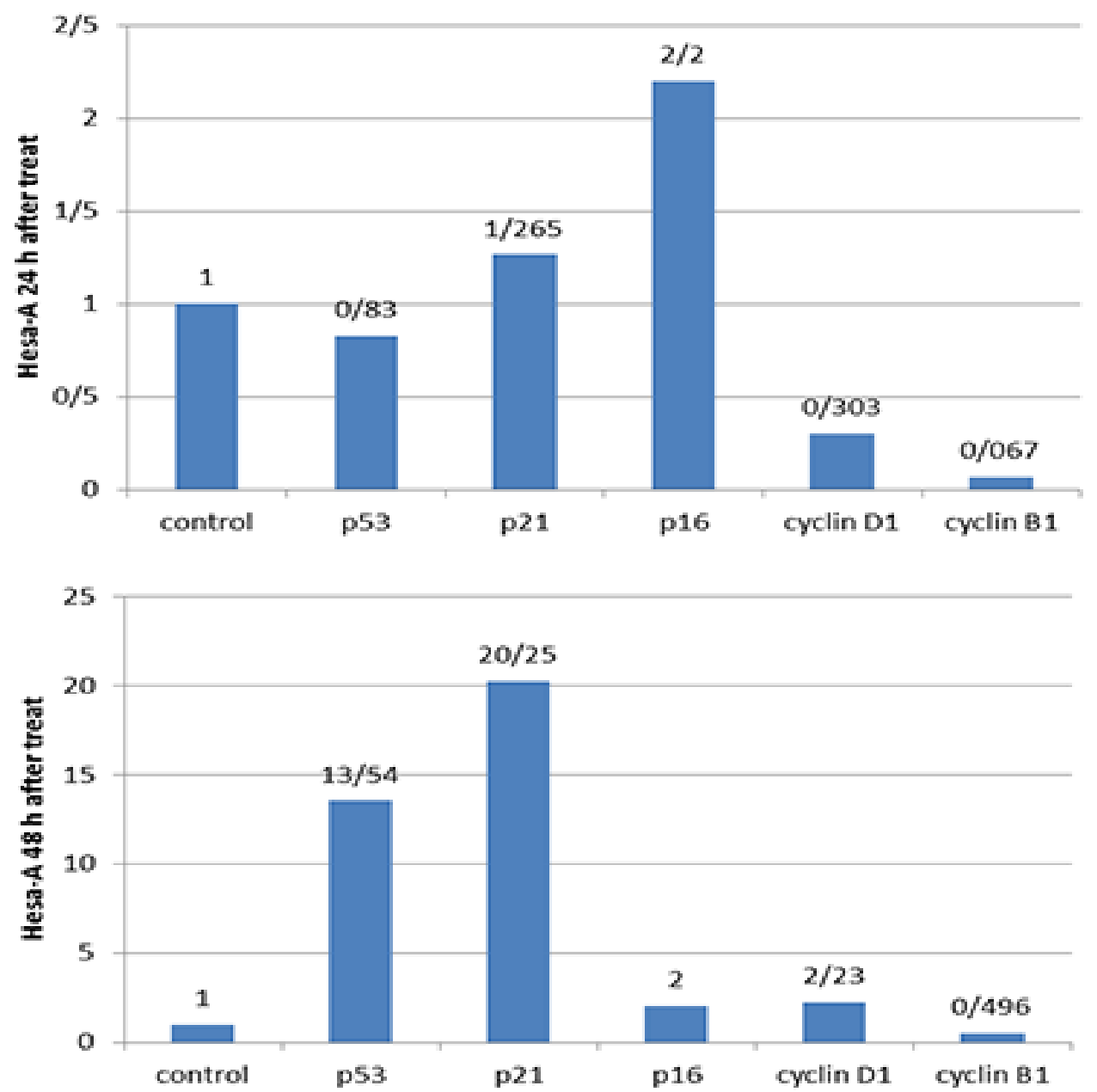

Fig.3: Real-time PCR analysis: All measured values were normalized to $\beta$-actin gene expression after (A) 24 and (B) 48 hours. The results related to increase in P53, P21, P16, cyclin B1, and cyclin D1 genes expression after Hesa-A treatment with $0.8 \mathrm{mg} / \mathrm{mL}$ concentration.

tion through declining the level of cyclin B, therefore arrest of cell cycle in $\mathrm{G} 2$ phase may occur. ${ }^{8,21,22}$

Almost all previous studies in this field evaluated the effect of Hesa-A on prevention of neoplasm or decreasing cell growth and increasing apoptosis in human or animal subjects.${ }^{11}$ Potent cytotoxic effects of Hesa-A on different human cancer cells have been reported in a newly published paper regarding the anti-proliferative effect of Hesa-A on MCF-7 (breast adenocarcinoma), SKOV3 (ovarian cancer), PC-3 (prostate adenocarcino$\mathrm{ma}$ ), and A549 (lung non-small cancer) cell lines. ${ }^{23}$

It could be suggested that $\mathrm{P} 21$ and $\mathrm{P} 16$ expressions are the main route for the cytotoxic effects of Hesa-A on esophageal cancer cells that arrest the G2 phase in the cell cycle.

\section{Authors' contributions}

Nasser Ahmadian, Roghiyeh Pashaei-Asl, Nasser Samadi, Mohammad Rahmati-yamchi, Mohammad-Reza Rashidi, Masomeh Ahmadian, Moosa Esmaeili, Faezeh Salamat, Sima Besharat and HamidReza Joshaghani have made substantial contributions to conception and design, acquisition of data, analysis and interpretation of data and agreement to be accountable for all aspects of the work in ensuring that questions related to the accuracy or integrity of any part of the work are appropriately investigated and resolved. All of them also have been involved in drafting the manuscript or revising it critically 
for important intellectual content and have given final approval of the version to be published.

\section{CONFLICT OF INTEREST}

The authors declare no conflict of interest related to this work.

\section{REFERENCES}

1. Abedi-Ardekani B, Kamangar F, Sotoudeh M, Villar S, Islami F, Aghcheli K, et al. Extremely high Tp53 mutation load in esophageal squamous cell carcinoma in Golestan Province, Iran. Plos One 2011;6:e29488. doi: 10.1371/journal. pone. 0029488 .

2. Koenig A, Bianco S, Fosmire S, Wojcieszyn J, Modiano J. Expression and significance of p53, rb, p21/waf-1, p16/ ink-4a, and PTEN tumor suppressors in canine melanoma Vet Pathol 2002;39:458-72. doi: 10.1354/vp.39-4-458

3. Xiong Y, Hannon GJ, Zhang H, Casso D, Kobayashi R, Beach D. p21 is a universal inhibitor of cyclin kinases. Nature 1993;366:701-4. doi:10.1038/366701a0

4. El-Deiry WS, Harper JW, O'Connor PM, Velculescu VE, Canman CE, Jackman J, et al. WAF1/CIP1 is induced in p53-mediated G1 arrest and apoptosis. Cancer Res 1994;54:1169-74.

5. Lane D. Cancer. A death in the life of p53. Nature 1993;362:786. doi:10.1038/362786a0

6. Dey S, Spring PM, Arnold S, Valentino J, Chendil D, Regine WF, et al. Low-dose fractionated radiation potentiates the effects of Paclitaxel in wild-type and mutant p53 head and neck tumor cell lines. Clin Cancer Res 2003;9:1557-65.

7. Shibata-Kobayashi S, Yamashita H, Okuma K, Shiraishi $\mathrm{K}$, Igaki H, Ohtomo K, et al. Correlation among 16 biological factors [p53, p21waf1, MIB-1 (Ki-67), p16INK4A, cyclin D1, E-cadherin, Bcl-2, TNF $\alpha$, NF- $\mathrm{kB}$, TGF- $\beta$, MMP-7, COX-2, EGFR, HER2/neu, ER, and HIF-1 $\alpha$ ] and clinical outcomes following curative chemoradiation therapy in 10 patients with esophageal squamous cell carcinoma. Oncol Lett 2013;5:903-10. doi:10.3892/ ol.2013.1130

8. Zhao M, Kim Y, Yoon B, Kim S, Kang M, Kim S, et al. Expression profiling of cyclin B1 and D1 in cervical carcinoma. Exp Oncol 2006;28:44-8.

9. Sadeghi-Aliabadi H, Ahmadi A. Cytotoxicity and Antitumor Properties of a Marine Compound, HESA-A, on Cancer Cells. DARU 2003;11:82-7.

10. Roudkenar MH, Bahmani P, Halabian R. HESA-A Exerts Its Cytoprotective Effects through Scavenging of Free Radicals: An in Vitro Study. Iran J Med Sci 2012;37:47.

11. Mehdipour M, Zenouz AT, Abbasi MM, Mohajeri D, Damghani H, Helli S, et al. Evaluation of the effect of two systemic doses of HESA-A on prevention of induced tongue neoplasm in rats. J Dent Res Dent Clin Dent Pros- pects. 2013;7:218. doi:10.5681/joddd.2013.035

12. Amrollah A, Gholamreza H, Mehdi F. Anticancer effects of HESA-A: An herbal marine compound. Chin J Integr Med 2010;16:366-7. doi: 10.1007/s11655-010-0517-x

13. Ahmadi A, Mohagheghi MA, Fazeli MS, Nahavandian B, Bashardoost N, Jarahi AM, et al. HESA-A: new treatment for breast cancer and choroidal metastasis. Med Sci Monit Basic Res 2005;11:CR300-CR3.

14. Ahmadi A, Naderi G, Asgary S. Evaluation of hepatoprotective potential of HESA-A (a marine compound) pretreatment against thioacetamide-induced hepatic damage in rabbits. Drugs Exp Clin Res 2004;31:1-6.

15. Nourazarian AR, Najar AG, Farajnia S, Khosroushahi AY, Pashaei-Asl R, Omidi Y. Combined EGFR and cSrc antisense oligodeoxynucleotides encapsulated with PAMAM Denderimers inhibit HT-29 colon cancer cell proliferation. Asian Pac J Cancer Prev 2012;13:4751-6.

16. Kato H, Yoshikawa M, Fukai Y, Tajima K, Masuda N, Tsukada K, et al. An immunohistochemical study of p16, pRb, p21 and p53 proteins in human esophageal cancers. Anticancer Res 1999;20:345-9.

17. Bates S, Vousden K. Mechanisms of p53-mediated apoptosis. Cell Mol Life Sci 1999;55:28-37. doi:10.1007/ s000180050267

18. GartelAL, Tyner AL. The role of the cyclin-dependent kinase inhibitor p21 in apoptosis. Mol Cancer Ther 2002;1:639-49.

19. Hunter T, Pines J. Cyclins and cancer II: cyclin D and CDK inhibitors come of age. Cell 1994;79:573-82.

20. Pagano M, Theodoras AM, Tam SW, Draetta GF. Cyclin D1-mediated inhibition of repair and replicative DNA synthesis in human fibroblasts. Genes Dev 1994;8:1627-39.

21. King RW, Jackson PK, Kirschner MW. Mitosis in transition. Cell 1994;79:563-71.

22. Innocente SA, Abrahamson JL, Cogswell JP, Lee JM. p53 regulates a G2 checkpoint through cyclin B1. Proc Natl Acad Sci U S A 1999;96:2147-52.

23. Jahanban-Esfahlan R, Abasi M, Sani HM, Abbasi MM, Akbarzadeh A. Anti-Proliferative Effects of Hesa-A on Human Cancer Cells with Different Metastatic Potential. Asian Pac J Cancer Prev 2015;16:6963-6. 